\title{
EFFECTS OF FERTILIZER N AND SOIL MOISTURE ON MINERALIZATION, N RECOVERY AND A-VALUES, UNDER SPRING WHEAT GROWN IN SMALL LYSIMETERS
}

\author{
C. A. CAMPBELL ${ }^{1}$ and E. A. PAUL ${ }^{2}$ \\ ${ }^{1}$ Research Station, Research Branch, Agriculture Canada, Swift Current, Saskatchewan $S 9 H 3 X 2$. \\ ${ }^{2}$ Saskatchewan Institute of Pedology, University of Saskatchewan, Saskatoon, Sask. S7N OWO. \\ Received 13 June 1977, accepted 23 Sept. 1977.
}

\begin{abstract}
Campbell, C. A. and Paul, E. A. 1978. Effects of fertilizer $\mathrm{N}$ and soil moisture on mineralization, $\mathrm{N}$ recovery and $\mathrm{A}$-values, under spring wheat grown in small lysimeters. Can. J. Soil Sci. 58: 39-51.
\end{abstract}

\begin{abstract}
The influence of rate of fertilizer $\mathrm{N}$ and soil moisture on $\mathrm{N}$ uptake by spring wheat, $\mathrm{N}$ mineralization, A-values and $\mathrm{N}$ recovery was determined in small lysimeters on stubble land by means of ${ }^{15} \mathrm{~N}$-labelled $\mathrm{KNO}_{3}$. Net mineralization was enhanced by frequent irrigations but depressed by cropping. In contrast to most growth chamber results, $\mathrm{N}$ uptake was not linearly but logarithmically related to rate of application; uptake from fertilizer was positively related to rate, but only up to a point beyond which it levelled off; uptake from native soil $\mathrm{N}$ was generally negatively related to rate; A-values were not constant but negatively related to rate except at the highest rates (123-164 kg N/ha) when they were positively related especially under dry conditions. These differences in results were credited to the fact that the pot system does not adequately simulate the field situation. On dryland an average of 68,20 and $12 \%$ of the plant $\mathrm{N}$ was located in the grain, straw and roots, respectively; under irrigation the corresponding values were 75,16 and $9 \%$. Average recovery of fertilizer $\mathrm{N}$ on dryland was: soil $34.6 \%$, grain $37.3 \%$, straw $12.2 \%$, roots $2.6 \%$, error $6.0 \%$, and unaccounted $7 \%$; under irrigation it was $15.4,58.3,13.0,3.5,6.0$ and $4.0 \%$, respectively. On dryland about $28 \%$ of the fertilizer $\mathrm{N}$ was left in the soil at rates up to $82 \mathrm{~kg} \mathrm{~N} / \mathrm{ha}$, while $57 \%$ was left at $164 \mathrm{~kg} \mathrm{~N} / \mathrm{ha}$; under irrigation the corresponding values were 15 and $21 \%$, respectively. On dryland $>70 \%$ of the residual $\mathrm{N}$ was located in the $0-$ to $30-\mathrm{cm}$ soil segment at fertilizer rates $<82 \mathrm{~kg}$ $\mathrm{N} / \mathrm{ha}$; at higher rates $>50 \%$ was in the $30-$ to $60-\mathrm{cm}$ segment. Only at $164 \mathrm{~kg} \mathrm{~N} / \mathrm{ha}$ was there appreciable residual $\mathrm{N}$ in the $30-$ to $60-\mathrm{cm}$ segment under irrigation. There was negligible fertilizer $\mathrm{N}$ below $60 \mathrm{~cm}$ in all treatments.
\end{abstract}

Dans de petits lysimètres installés sur chaume, on a déterminé, au moyen de $\mathrm{KNO}_{3}$ marqué $\left({ }^{15} \mathrm{~N}\right)$, l'incidence du taux de fumure azotée et de la teneur en eau du sol sur l'absorption de $\mathrm{N}$ par le blé de printemps, les valeurs $\mathrm{A}$, la minéralisation et la récupération de $\mathrm{N}$. Les irrigations fréquentes ont accru la minéralisation nette, mais les cultures l'ont réduite. Contrairement à la plupart des résultats obtenus en chambre de croissance, l'absorption de $\mathrm{N}$ affichait une corrélation logarithmique positive (non linéaire) à la dose d'épandage, mais seulement jusqu'à un seuil au-delà duquel elle se stabilisait; par contre, celle de $\mathrm{N}$ natif du sol montrait généralement une corrélation négative à la doze d'épandage; les valeurs A étaient irrégulières et affichaient une corrélation négative, sauf au plus fortes doses (123-164 kg de N/ha) et particulièrement sans irrigation. Ces différences dans les résultats ont été attribuées au fait que les lysimètres ne simulent pas correctement la situation au champ. Sans irrigation, le grain, la paille et les racines contenaient en moyenne 68 , 20 et $12 \%$ respectivement du $\mathrm{N}$ total des plants par rapport à 75,16 et $9 \%$ en irrigation. La récupération moyenne de $\mathrm{N}$ sans irrigation était, dans l'ordre, de $34.6 \%$ par le sol, $37.3 \%$ par le grain, $12.2 \%$ par la paille, $2.6 \%$ par les racines,

Can. J. Soil Sci. 58: 39-51 (Feb. 1978) 
$6.0 \%$ d'erreur et $7.0 \%$ de cause indéterminée, comparativement à $15.4,58.3,13.0$, 6.0 et 4.0 respectivement en irrigation. Sans irrigation, environ $28 \%$ de la fumure azotée est restée dans le sol jusqu'à concurrence de $82 \mathrm{~kg}$ de N/ha, alors que celui-ci en retenait $57 \%$ à la dose de $164 \mathrm{~kg}$ de $\mathrm{N} / \mathrm{ha}$; en irrigation, les valeurs correspondantes étaient de 15 et $21 \%$ respectivement. Sans irrigation, plus de $70 \%$ du $\mathrm{N}$ résiduel se situait dans les 30 premiers centimètres du sol aux doses de fumure inférieures à $82 \mathrm{~kg}$ de $\mathrm{N} / \mathrm{ha}$; aux plus fortes doses, plus de $50 \%$ se retrouvait dans la couche de $30-60 \mathrm{~cm}$. Ce n'est qu'à $164 \mathrm{~kg}$ de N/ha, en irrigation, qu'on a observé une quantité appréciable de $\mathrm{N}$ résiduel dans cette couche. Pour tous les traitements, on n'a retrouvé que des quantités négligeables de $\mathrm{N}$ en dessous de $60 \mathrm{~cm}$.

At the present rate of world population expansion, agricultural production will be taxed to keep pace with the consumption of food and fibre. Although increased application of $\mathrm{N}$ is required to maximize the production of high-quality crops, there is the danger of possible pollution of ground waters, and the atmosphere and eutrophication of lakes. Research must find ways to increase the efficiency of plant use of fertilizer $\mathrm{N}$, since this will increase yields and reduce the pollution potential.

Numerous fertilizer studies have been carried out in which ${ }^{15} \mathrm{~N}$-labelled materials have been used. However, as stressed by Hauck (1973), " few studies provide quantitative information... or information which is useful for calculating $\mathrm{N}$ balance in the total biosphere." 'Furthermore, most N balance studies have been conducted in the laboratory or greenhouse. The results obtained in such studies may be quite different from those found under field conditions.

Kundler (1970) summarized ${ }^{15} \mathrm{~N}$ results obtained under various experimental conditions. He reported 1st yr plant recoveries of fertilizer $\mathrm{N}$ ranging from 30 to $70 \%$, with $10-40 \%$ left in the soil, $5-10 \%$ lost by leaching, and 10-30\% unaccounted for. In a comprehensive review of the fate of fertilizer $\mathrm{N}$ under controlled conditions, Allison (1966) concluded that the efficiency of any $\mathrm{N}$ carrier will be a function of (a) losses due to leaching, denitrification and other processes leading to gaseous losses; (b) the rate of immobilization of $\mathrm{N}$; (c) the ratio of soil $\mathrm{N} /$ fertilizer $\mathrm{N}$ in the available $\mathrm{N}$ pool; and (d) $\mathrm{NH}_{4}$ fixation by soil colloids. Environmental factors such as moisture and temperature will also affect $\mathrm{N}$ transformation indirectly by influencing plant growth and $\mathrm{N}$ uptake.

Field studies using ${ }^{15} \mathrm{~N}$ have been carried out with wheat as the test crop (Myers and Paul 1971; Paul et al. 1972), forages (Westerman et al. 1972; Carter et al. 1967), maize and rice (Rennie and Fried 1971), and forests (Overrein 1972). In a recent field study carried out in semiarid southwestern Saskatchewan, Campbell and coworkers examined the influence of rate of fertilizer $\mathrm{N}$ application and soil moisture on the growth and moisture use (Campbell et al. 1977a), $\mathrm{N}$ accumulation, yield and yield components of spring wheat (Campbell et al. 1977b). This study presented an opportunity to use ${ }^{15} \mathrm{~N}$-labelled fertilizer to determine the influence of moisture and rate of fertilizer $\mathrm{N}$ on the efficiency of use of fertilizer and soil $\mathrm{N}$, and to construct a balance sheet for fertilizer $\mathrm{N}$ under field conditions.

\section{MATERIALS AND METHODS}

General field and weather characteristics and experimental techniques for this study have been described previously (Dyck et al. 1977; Campbell et al. 1977a,b). Thus, only a brief outline and information pertinent to this experiment, but which was not previously presented, will be described here.

During the 1975 growing season, spring wheat (Triticum aestivum L. cv. Manitou) was grown in metal lysimeters on a Wood Mountain loam (Mitchell et al. 1944) in a stubble wheat field which contained $18 \mathrm{~kg} \mathrm{NO}_{3}-\mathrm{N} /$ ha in the top $60 \mathrm{~cm}$ at seeding. Two soil moisture regimes [natural rainfall (dry) and irrigated (wet)], seven rates of $\mathrm{N}(0,37.5,75,112.5,150,225$, and $300 \mathrm{mg} \mathrm{NO}_{3}-\mathrm{N} /$ lysimeter), and five times of 
sampling (3-leaf, tillering, shot blade, anthesis and maturity) were combined factorially. The seven rates of fertilizer are equivalent to $0,20.5$, $41,61.5,82,123$, and $164 \mathrm{~kg} \mathrm{~N} / \mathrm{ha}$. The fertilizer was applied as $\mathrm{KNO}_{3}$ powder. Only the lysimeters that were sampled at maturity received ${ }^{15} \mathrm{~N}$-labelled $\mathrm{KNO}_{3}\left(5.525\right.$ atom $\left.\%{ }^{15} \mathrm{~N}\right)$. A total of $17.8 \mathrm{~cm}$ of distilled water was applied to the irrigated treatments. The various nontracer soil and plant analyses carried out (e.g., exchangeable $\mathrm{NH}_{4}-\mathrm{N}, \mathrm{NO}_{3}-\mathrm{N}$, plant weight, plant $\mathrm{N}$, soil density, temperatures, moisture, etc.) are presented elsewhere (Dyck et al. 1977; Campbell et al. 1977a,b).

\section{Mass Spectrometric Analysis}

Separate subsamples of soil, grain, straw and roots taken at maturity were used for mass spectrometric analysis. Soil from the various segments was combined to provide samples for depths of $0-15,15-30,30-60,60-90$ and 90-105 cm. Roots were combined to represent depths of $0-15$ and $>15 \mathrm{~cm}$. Total $\mathrm{N}$, including $\mathrm{NO}_{3}{ }^{-}$and $\mathrm{NO}_{2}-\mathrm{N}$, was determined using a modified semi-micro version of the method of Bremner (1965) as outlined by Rennie and Paul (1971). Soil samples were pretreated with acidified permanganate to oxidize $\mathrm{NO}_{2^{-}}$to $\mathrm{NO}_{3}-\mathrm{N}$, and with reduced iron and sulfuric acid to reduce the $\mathrm{NO}_{3}$ - to $\mathrm{NH}_{4}-\mathrm{N}$. None of the plant material required this pretreatment because earlier determinations showed that $\mathrm{NO}_{3}-\mathrm{N}$ constituted $<1 \%$ of their total N. A Kjeldahl digestion was used to convert organic $\mathrm{N}$ to $\mathrm{NH}_{4}-\mathrm{N}$. Isotope-ratio analys is was performed on an Atlas GD 150 mass spectrometer.

\section{Calculations}

The atom $\%$ excess, $\% \mathrm{~N}$ derived from fertilizer (\% NDFF), \% recovery of fertilizer $\mathrm{N}$ in plant parts, A-value for $\mathrm{N}$ and the amount of plant and soil $\mathrm{N}$ derived from the fertilizer and soil sources were calculated by methods outlined by Rennie and Paul (1971). The results were analyzed using a randomized block design. Tukey's $\omega$ value (Steel and Torrie 1960) was used to test appropriate differences between means.

\section{Growing Season Conditions}

During the 1975 growing season (Campbell et al. 1977a), there was good soil moisture from seeding to midway between tillering and shot blade stages of growth. This was followed by about 4 wk of drought $(<1 \mathrm{~cm}$ of rain) which lasted until anthesis. Thereafter there was consistent rainfall $(6-12 \mathrm{~cm})$ to maturity.

\section{RESULTS AND DISCUSSION Mineralization During the Growing Sea- son}

Net mineralization in a well-aerated soil will be reflected by changes in its $\mathrm{NO}_{3}$ - and exchangeable $\mathrm{NH}_{4}-\mathrm{N}$ and the plant $\mathrm{N}$ content. In this study the amount of exchangeable $\mathrm{NH}_{4}-\mathrm{N}$ was low (4-6 ppm); it was not affected by rate of $\mathrm{N}$, soil moisture treatment, growth stage or cropping. Consequently, all changes in mineral $\mathrm{N}$ were examined in terms of $\mathrm{NO}_{3}-\mathrm{N}$ (Campbell et al. 1977a).

The $\mathrm{NO}_{3}-\mathrm{N}$ was used up rapidly by the crop under wet conditions. Only at rates equal to or greater than $82 \mathrm{~kg} \mathrm{~N} /$ ha under dryland, and at $164 \mathrm{~kg} \mathrm{~N} / \mathrm{ha}$ under irrigation, was there appreciable $\mathrm{NO}_{3}-\mathrm{N}$ found in the soil at maturity. Based on the $\mathrm{NO}_{3}-\mathrm{N}$ changes observed in the summer-fallow treatment it appeared that considerable mineralization occurred between seeding and tillering and between anthesis and maturity under dry conditions (Campbell et al. 1977a). Due to continual plant uptake, comparing changes in $\mathrm{NO}_{3}-\mathrm{N}$ levels provides only a rough approximation of mineralization. A better estimate of the amount of the net mineralization taking place throughout the growing season was obtained from Table 1 as follows: Net mineralization during a period $=\left[\left(\mathrm{NO}_{3}-\mathrm{N}\right.\right.$ in soil + plant- $\mathrm{N})$ at any time less $\left(\mathrm{NO}_{3}-\mathrm{N}\right.$ in soil + plant-N) at an earlier time]. This does not account for re-immobilization of mineralized $\mathrm{N}$. It can be seen that mineralization did occur under wet conditions even though this was not reflected in the $\mathrm{NO}_{3}-\mathrm{N}$ results (Campbell et al. 1977a).

Net mineralization up to anthesis or maturity was generally greater under wet than dry conditions (Table 1). Cropping also tended to depress net mineralization. For example, during the period from 3-leaf to anthesis there was little net mineralization. This effect has been noted by others (Allison 1973; Ford et al. 1974). It has been credited to the "rhizosphere effect," largely associated with the production of 
exudates and sloughed-off cell debris from the roots (Rovira and McDougall 1967).

Uptake and Distribution of $\mathbf{N}$ in the Plant

Total N uptake by wheat grown on stubble land under dry conditions in 1975 was $58 \mathrm{~kg}$ $\mathrm{N} / \mathrm{ha}$ (Table 2). The addition of $\mathrm{N}$ and water increased $\mathrm{N}$ uptake. When $164 \mathrm{~kg} \mathrm{~N} / \mathrm{ha}$ was applied, $\mathrm{N}$ uptake on dryland increased by $76 \%$ to $102 \mathrm{~kg} \mathrm{~N} / \mathrm{ha}$; when $17.8 \mathrm{~cm}$ of water was applied, $\mathrm{N}$ uptake increased by $60 \%$ to $93 \mathrm{~kg} \mathrm{~N} / \mathrm{ha}$; and when both $164 \mathrm{~kg} \mathrm{~N} / \mathrm{ha}$ and $17.8 \mathrm{~cm}$ of water were applied, $\mathrm{N}$ uptake increased by $210 \%$ to $180 \mathrm{~kg} \mathrm{~N} / \mathrm{ha}$.

Crop dry matter response to increasing rates of fertilizer $\mathrm{N}$ is usually curvilinear (Viets, Jr. 1965; Campbell et al. 1977a) and may be fitted with various second-degree or logarithmic equations. Yield-of-nutrient curves tend to be linear, especially where studies are conducted in pot culture (Terman and Brown 1968; Allison 1973). Often when the regression method is used to calculate recovery of fertilizer $\mathrm{N}$ by the crop (Terman and Brown 1968; Westerman and Kurtz 1974), this linear relationship is assumed to provide the best response relationship. In our field study, although a linear plot of the data gave a significant correlation $(r=0.83)$, the response surface was better fitted by a Mitscherlich type of equation under dry conditions (Fig. 1a) or a simple power function type relationship under wet conditions (Fig. 1b). Based on data from field trials, Soper et al. (1971) found that the uptake of $\mathrm{N}$ by barley could be predicted from the soil $\mathrm{N}$ present at seeding time by means of a parabolic function. Such quantitative relationships can serve as a useful tool for predicting yields (Soper et al. 1971) and for constructing quantitative models of the effects of soil and weather conditions on the response of crops to $\mathrm{N}$ fertilizer (Greenwood et al. 1974).

The $\mathrm{N}$ taken up was translocated efficiently and was independent of levels of fertilizer $\mathrm{N}$ under irrigation (Table 2). Under dryland conditions, an average of 68, 20 , and $12 \%$ of the plant's $\mathrm{N}$ at maturity was located in the grain, straw and roots, respectively; under irrigation, the corresponding values were 75,16 and $9 \%$. Thus there was an average of $7 \%$ more $\mathrm{N}$ left in the vegetative parts (roots $3 \%$, straw $4 \%$ )

Table 1. N recovered in plant and soil at various growth stages

\begin{tabular}{|c|c|c|c|c|c|c|c|c|c|}
\hline \multirow{2}{*}{$\begin{array}{l}\text { Sampling time and } \\
\text { moisture treatment }\end{array}$} & & \multicolumn{8}{|c|}{$\mathrm{N}$ applied (mg/lysimeter) $\dagger$} \\
\hline & & $0:$ & 0 & 37.5 & 75 & 112.5 & 150 & 225 & 300 \\
\hline & $(\mathrm{DAE}) \S$ & & 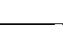 & $\operatorname{ant} \mathrm{Np}$ & $\mathrm{NO}_{3}-\mathrm{I}$ & soil (mg & simete & & \\
\hline \multicolumn{10}{|c|}{ (2) } \\
\hline Initially & - & 37 & 37 & 75 & 112 & 150 & 187 & 262 & 337 \\
\hline 3-leaf & (14) & 65 & 74 & 107 & 147 & 185 & 255 & 310 & 385 \\
\hline Tillering & (25) & 114 & 87 & 125 & 130 & 190 & 220 & 275 & 410 \\
\hline Shot blade & (39) & 105 & 120 & 135 & 155 & 167 & 240 & 275 & 340 \\
\hline Anthesis & (51) & 117 & 105 & 130 & 142 & 173 & 212 & 280 & 362 \\
\hline Avg maturity & (85) & 225 & 132 & 160 & 207 & 260 & 237 & 305 & 432 \\
\hline \multicolumn{10}{|l|}{ Wet } \\
\hline Initially & - & - & 37 & 75 & 112 & 150 & 187 & 262 & 337 \\
\hline 3-leaf & (14) & - & 77 & 112 & 135 & 167 & 207 & 275 & 345 \\
\hline Tillering & (25) & - & 82 & 120 & 162 & 215 & 202 & 295 & 360 \\
\hline Shot blade & (39) & - & 100 & 126 & 159 & 182 & 224 & 262 & 360 \\
\hline Anthesis & (51) & - & 116 & 132 & 160 & 227 & 232 & 255 & 345 \\
\hline Avg maturity & (85) & - & 185 & 247 & 300 & 297 & 305 & 320 & 397 \\
\hline
\end{tabular}

$\dagger \mathrm{mg} \mathrm{N} /$ lysimeter $\times 0.548=\mathrm{kg} \mathrm{N} / \mathrm{ha}$.

$\ddagger$ This was a summer fallow treatment; all others were cropped.

§DAE, days after emergence. 
under dryland than under irrigation. As suggested previously (Campbell et al. $1977 \mathrm{~b}$ ), some $\mathrm{N}$ present in the straw under dryland conditions was probably "denatured" during the prolonged drought which occurred between tillering and anthesis. Consequently, translocation of $\mathrm{N}$ from straw to grain was impeded under dryland conditions at the higher fertilizer $\mathrm{N}$ rates (Table 2) where the soils dried out much more rapidly.

\section{Recovery of Fertilizer and Soil $\mathbf{N}$ by the Plant}

The proportion of the plant $\mathrm{N}$ (grain, straw, roots) that was derived from fertilizer $\mathrm{N}$ (\% NDFF) increased with the rate of $N$ application to a maximum at about $82 \mathrm{~kg} / \mathrm{ha}$ under dry conditions and $123 \mathrm{~kg} / \mathrm{ha}$ under irrigation and then levelled off (Table 2). Similar to the findings of Paul et al. (1972), $\%$ NDFF was the same for straw and grain. Thus, one should be able to estimate the ${ }^{15} \mathrm{~N}$ abundance for grain by measuring ${ }^{15} \mathrm{~N}$ abundance in straw and vice versa. The $\%$ NDFF was considerably lower in the roots than in the aboveground parts. Thus, root ${ }^{15} \mathrm{~N}$ abundance must be determined, especially if the sample is taken at maturity. The lower \% NDFF in roots might be an indication that some of the $\mathrm{N}$ previously present in the roots was translocated to the tops and that most of the $\mathrm{N}$ present in the roots at maturity was taken up from a pool

Table 2. Effects of fertilizer $\mathrm{N}$ and moisture on $\mathrm{N}$ uptake by the plant, $\mathrm{N}$ distribution among plant parts and the source of $\mathrm{N}$ found in the plant parts at maturity

\begin{tabular}{|c|c|c|c|c|c|c|c|c|c|}
\hline \multirow{2}{*}{$\begin{array}{l}\text { Plant part and } \\
\text { moisture treatment }\end{array}$} & \multicolumn{7}{|c|}{$\mathrm{N}$ applied (kg/ha) } & \multicolumn{2}{|c|}{$\ddagger \omega(P<0.05)$} \\
\hline & 0 & 20.5 & 41 & 61.5 & 82 & 123 & 164 & Moisture & $\mathbf{N}$ \\
\hline \multicolumn{10}{|c|}{ Plant N uptake $(\mathrm{kg} / \mathrm{ha})$} \\
\hline Dry & 58.1 & 63.4 & 75.9 & 84.6 & 91.4 & 92.4 & 101.7 & \multirow{2}{*}{9.0} & \multirow{2}{*}{20.1} \\
\hline Wet & 93.2 & 129.2 & 144.1 & 149.2 & 157.9 & 185.0 & 180.3 & & \\
\hline \multicolumn{10}{|c|}{$\%$ of plant $N$ found in plant parts } \\
\hline Grain & & & & & & & & \multirow{3}{*}{2.2} & \multirow{3}{*}{6.2} \\
\hline Dry & 75.9 & 68.6 & 67.5 & 61.1 & 67.6 & 69.2 & 69.3 & & \\
\hline Wet & 74.0 & 75.1 & 76.1 & 76.3 & 73.8 & 77.9 & 74.5 & & \\
\hline \multicolumn{10}{|l|}{ Straw } \\
\hline Dry & 14.6 & 16.5 & 20.3 & 26.2 & 21.3 & 20.7 & 20.0 & \multirow{2}{*}{1.6} & \multirow{2}{*}{4.8} \\
\hline Wet & 15.8 & 15.5 & 16.3 & 15.3 & 17.4 & 12.2 & 15.3 & & \\
\hline \multicolumn{10}{|l|}{ Roots } \\
\hline Dry & 9.5 & 14.9 & 12.2 & 12.7 & 11.1 & 10.1 & 10.8 & \multirow[b]{2}{*}{1.6} & \multirow[b]{2}{*}{4.7} \\
\hline Wet & 10.3 & 9.3 & 7.6 & 8.4 & 8.8 & 9.9 & 10.2 & & \\
\hline \multicolumn{10}{|c|}{$\%$ of plant part $N$ derived from fertilizer $(\% N D F F) \dagger$} \\
\hline Grain & & & & & & & & \multirow{3}{*}{ ND } & \multirow{3}{*}{ ND } \\
\hline Dry & - & 19 & 33 & 52 & 61 & 57 & 53 & & \\
\hline Wet & - & 12 & 18 & 32 & 45 & 60 & 61 & & \\
\hline \multicolumn{10}{|l|}{ Straw } \\
\hline Dry & - & 24 & 36 & 53 & 60 & 57 & 51 & \multirow{2}{*}{ ND } & \multirow{2}{*}{ ND } \\
\hline Wet & - & 15 & 23 & 37 & 47 & 59 & 60 & & \\
\hline \multicolumn{10}{|l|}{ Roots } \\
\hline Dry & - & 8 & 7 & 17 & 26 & 31 & 28 & \multirow{2}{*}{ ND } & \multirow{2}{*}{$\mathrm{ND}$} \\
\hline Wet & - & 5 & 16 & 17 & 24 & 26 & 25 & & \\
\hline
\end{tabular}

$\uparrow\left(\frac{{ }^{15} \mathrm{~N} \text { excess in sample }}{{ }^{15} \mathrm{~N} \text { excess in fertilizer }}\right) \times 100=\% \mathrm{NDFF}$.

$\ddagger \omega(P<0.05)$ is the difference required for significance at the 5\% level of probability according to Tukey's method; $\mathrm{ND}$, not determined. 
of $\mathrm{N}$ now much lower in fertilizer $\mathrm{N}$ than was originally the case.

The \% NDFF was used to calculate the amount of aboveground plant $\mathrm{N}$ derived from the fertilizer and that which came from the soil (Table 3). Rennie and Fried (1971) have shown that where the dilution of applied ${ }^{15} \mathrm{~N}$ label is primarily a function of a single variable (e.g. rate of fertilizer application), \% NDFF will provide conclusions identical to those provided by $\mathrm{N}$ uptake per unit area. Our results confirmed this (compare response of $\%$ NDFF and NDFF to $\mathrm{N}$ applied). However, when a second interacting variable such as moisture is introduced, \% NDFF can no longer be used to assess comparative fertilizer $\mathrm{N}$ utilization; instead, a yield-dependent criterion based on the ${ }^{15} \mathrm{~N}$ data is required (Rennie and Fried 1971). This point is borne out by the fact that the amount of NDFF is greater under wet conditions than on dryland (Table 3 ) although the \% NDFF is greater (at rates of $\mathrm{N} \leqslant 82 \mathrm{~kg} / \mathrm{ha}$ ) on dryland than under irrigation (Table 2).

Most $\mathrm{N}$ isotope studies that have been carried out in controlled environments indicate that there is a positive relationship between rate of uptake of soil $\mathrm{N}$ and rate of fertilizer $N$ application (Allison 1973; Aleksic et al. 1968). Myers and Paul (1971), in a field tracer study with wheat, did not find an increase in the uptake of soil $\mathrm{N}$ by the plant due to increased fertilizer $\mathrm{N}$. We found that increased fertilizer $\mathrm{N}$ generally depressed the uptake of soil N (Table 3 ). Only at the lowest rates of fertilizer under irrigation was there an indication of a positive relationship. Those workers who have found a positive relationship between soil $\mathrm{N}$ uptake and fertilizer $\mathrm{N}$ applied have credited this to various mechanisms. Some of these are: priming effect, turnover of $\mathrm{N}$, rhizosphere effect, increased root growth, salt or osmotic effects (Allison 1973), and the protolytic effect (Laura 1976).

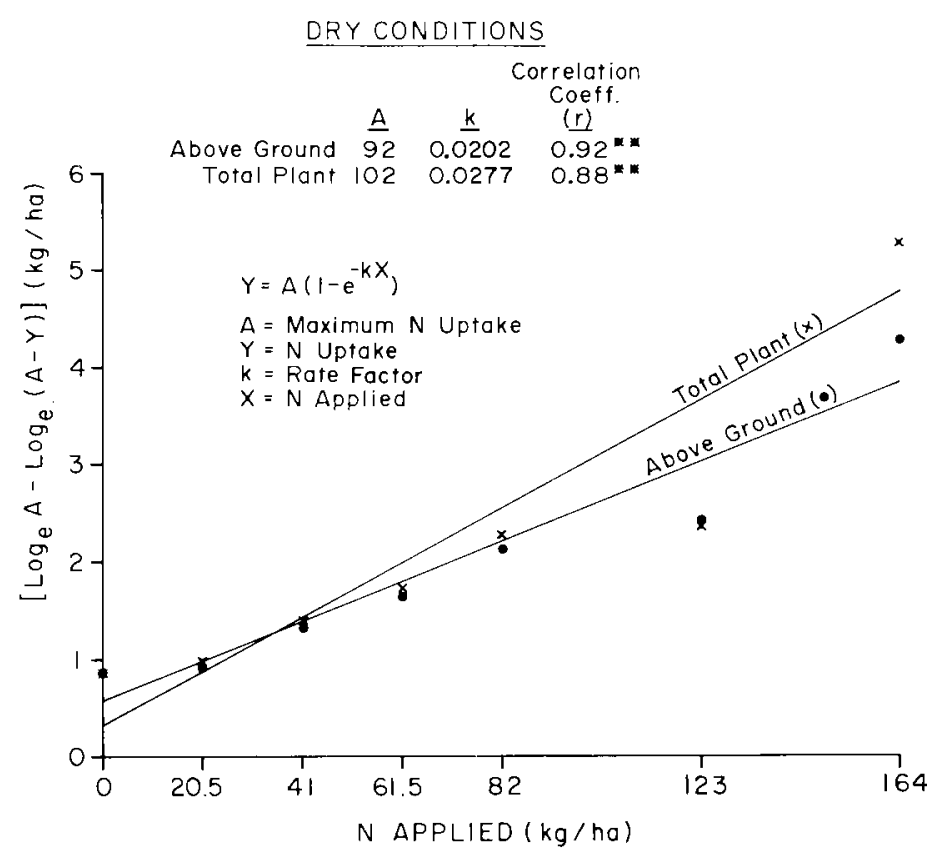

Fig. 1a. Quantitative effect of fertilizer $\mathrm{N}$ and moisture on uptake of $\mathrm{N}$ in total plant and aboveground parts - dry conditions. 
In a review of how different variables affect A-values, Broadbent (1970) noted that A-values may increase, decrease, or remain constant with increased rate of fertilizer N. Our results showed that there was an interaction between $\mathrm{A}$-value and rate of $\mathrm{N}$ applied (Table 3). A-values generally tended to decrease with increasing fertilizer to $82 \mathrm{~kg} \mathrm{~N} / \mathrm{ha}$ (dry) or $123 \mathrm{~kg} \mathrm{~N} / \mathrm{ha}$ (wet) and then increased considerably under dry conditions. In most growth chamber studies (Aleksic et al. 1968; Legg and Stanford 1967; Smith and Legg 1971), the A-values tended to remain constant even though $\mathrm{N}$ uptake from soil tended to increase with $\mathrm{N}$ applied. In our study, A-values and soil $\mathrm{N}$ uptake curves were similar up to a point [e.g. $r=0.64^{*}$ (dry); 0.78* (wet)]; however, while the A-values indicated an increased availability of soil $\mathrm{N}$ at high rates of fertilizer under dry conditions, the NDFS response to fertilizer did not reveal this. As will be shown later, this increase in A-values coincided with treatments where the greatest amount of residual fertilizer $\mathrm{N}$ was left in the soil. It was interesting to note that there was no indication of increased soil $N$ availability when a "difference", method such as that used earlier to determine net mineralization (Table 1) was

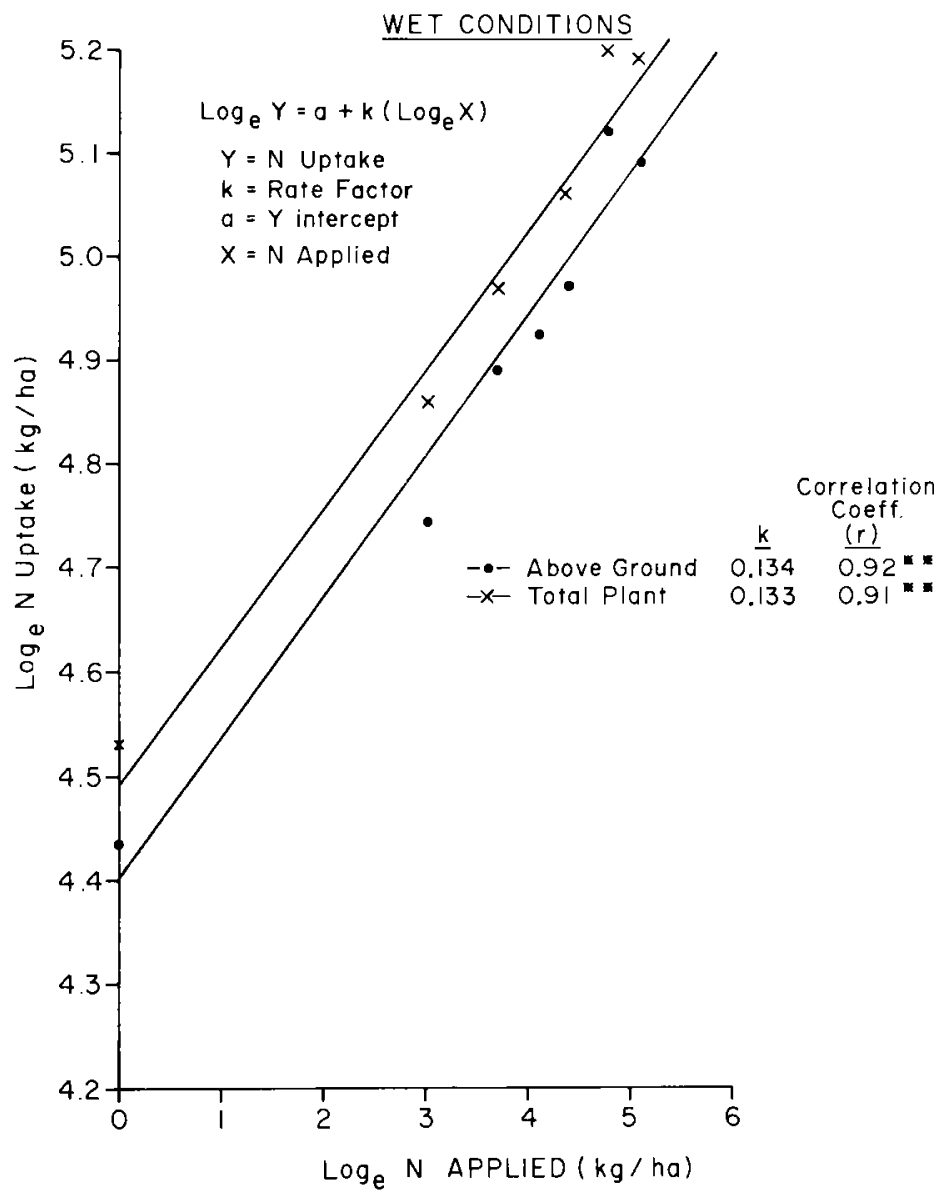

Fig. 1b. Quantitative effect of fertilizer $\mathrm{N}$ and moisture on uptake of $\mathrm{N}$ in total plant and aboveground parts - wet conditions. 
employed. Our results do not provide an answer as to which mechanism is responsible for the increase in soil $\mathrm{N}$ availability. Laura (1976) has suggested that a protolytic mechanism might be responsible, while Broadbent and Nakashima (1971) have suggested that this increase may be due to osmotic effects.

The proportion of the fertilizer $\mathrm{N}$ which was recovered by the total plant varied from 31 to $65 \%$ under dryland, and from 63 to $84 \%$ under irrigation (Table 3 ). The recovery was related to the influence of fertilizer $\mathrm{N}$ on dry matter production up to fertilizer rates of $61.5 \mathrm{~kg} \mathrm{~N} / \mathrm{ha}$ under dryland conditions, and up to $123 \mathrm{~kg} \mathrm{~N} / \mathrm{ha}$ under irrigation (see dry matter response, Campbell et al. 1977a). The decreasing recovery at high rates of $\mathrm{N}$ reflect the fact that although the applied ${ }^{15} \mathrm{~N}$ was increasing, plant ${ }^{15} \mathrm{~N}$ content (NDFF) remained constant at or above these high levels of $\mathrm{N}$. But, under dryland, $N\left({ }^{15} \mathrm{~N}+{ }^{14} \mathrm{~N}\right)$ tended to increase at high $\mathrm{N}$ rates (Table 2) due to increased use of the native soil ${ }^{14} \mathrm{~N}$ (NDFS, Table 3). The latter would therefore tend to indicate that this increased availability of soil $\mathrm{N}$ was at least partly responsible for the decrease in the recovery of fertilizer $\mathrm{N}$ by the plant at the highest rate of fertilizer application.

When the "difference method" was used to calculate the efficiency of fertilizer recovery by the plants, recovery decreased with increasing rate of fertilizer (Campbell et al. 1977b). The values varied from $35 \%$ at $41 \mathrm{~kg} \mathrm{~N} /$ ha to $23 \%$ at $164 \mathrm{~kg} \mathrm{~N} / \mathrm{ha}$ (dry conditions) and from 120 to $49 \%$ at similar rates under wet conditions. These results are opposite to those obtained by using the isotope method. We therefore concur with the sentiments of Rennie and Fried (1971), and Terman and Brown (1968) who concluded that the "difference method" provides results which are difficult to interpret, and should be used with extreme caution. Allison (1973), using results from a growth chamber study, reported that much lower recovery values were obtained by the ${ }^{15} \mathrm{~N}$ procedure than by difference. Although Allison points out that either low or high values may be obtained by the difference

Table 3. Effects of fertilizer $\mathrm{N}$ and moisture on the amount of each source of $\mathrm{N}$ found in aboveground parts, on A-values, and on the proportion of the fertilizer $\mathrm{N}$ found in the total plant and in soil at maturity

\begin{tabular}{|c|c|c|c|c|c|c|c|c|c|}
\hline \multirow{2}{*}{$\begin{array}{l}\text { Moisture } \\
\text { treatment }\end{array}$} & \multicolumn{7}{|c|}{$\mathrm{N}$ applied (kg/ha) } & \multicolumn{2}{|c|}{$\omega(P<0.05) \ddagger$} \\
\hline & 0 & 20.5 & 41 & 61.5 & 82 & 123 & 164 & Moisture & $\mathrm{N}$ \\
\hline \multicolumn{10}{|c|}{ Nitrogen derived from fertilizer $(N D F F) \dagger(k g / h a)$} \\
\hline Dry & - & 11.0 & 21.8 & 38.4 & 49.6 & 47.2 & 47.2 & \multirow{2}{*}{4.9} & \multirow{2}{*}{13.1} \\
\hline Wet & - & 15.3 & 25.3 & 44.4 & 64.8 & 100.2 & 97.9 & & \\
\hline \multicolumn{10}{|c|}{ Nitrogen derived from soil $(N D F S) \dagger(\mathrm{kg} / \mathrm{ha})$} \\
\hline Dry & 52.5 & 43.2 & 45.0 & 35.5 & 31.6 & 36.0 & 43.6 & \multirow{2}{*}{5.4} & \multirow{2}{*}{13.7} \\
\hline Wet & 83.7 & 102.4 & 107.8 & 92.2 & 79.2 & 66.7 & 63.8 & & \\
\hline \multicolumn{10}{|c|}{ A-value $\dagger(\mathrm{kg} / \mathrm{ha})$} \\
\hline Dry & - & 109 & 116 & 78 & 72 & 132 & 211 & \multirow{2}{*}{30} & \multirow{2}{*}{52} \\
\hline Wet & - & 187 & 239 & 175 & 137 & 112 & 148 & & \\
\hline \multicolumn{10}{|c|}{ Proportion of fertilizer $N$ recovered in plant $(\%)$} \\
\hline Dry & - & 57 & 55 & 65 & 63 & 41 & 31 & \multirow{2}{*}{6} & \multirow{2}{*}{15} \\
\hline Wet & - & 75 & 67 & 76 & 83 & 84 & 63 & & \\
\hline \multicolumn{10}{|c|}{ Proportion of fertilizer $N$ recovered in soil $(\%)$} \\
\hline Dry & - & 28 & 31 & 28 & 26 & 37 & 57 & \multirow{2}{*}{2} & \multirow{2}{*}{4} \\
\hline Wet & - & 15 & 15 & 14 & 14 & 15 & 21 & & \\
\hline
\end{tabular}

$\uparrow$ Based on $\mathrm{N}$ in aboveground parts only.

$\ddagger \omega(P<0.05)$ is the difference required for significance at the $5 \%$ level of probability according to Tukey's method. 
method under "well-understood" conditions, he also states that the two methods give generally similar recovery values. We believe Allison's results were due to the fact that they were obtained in pot experiments. These differences underline the difficulty in transposing results from the laboratory to the field.

\section{Residual Fertilizer $\mathbf{N}$ in the Soil}

About $28 \%$ of the fertilizer $\mathrm{N}$ was left in the soil profile following rates of application up to $82 \mathrm{~kg} \mathrm{~N} / \mathrm{ha}$ on dryland; at higher rates as much as $57 \%$ of the applied $\mathrm{N}$ was left in the soil (Table 3); only $15-21 \%$ was left in the soil under irrigation. The fate of the residual $\mathrm{N}$ is uncertain. Several workers (Jansson 1963; Legg et al. 1971; Broadbent and Nakashima 1967; Shields et al. 1973) have shown that under both growth chamber and field conditions most of this $\mathrm{N}$ becomes immobilized or changed into a form which, though temporarily more available than humus $\mathrm{N}$, is only slowly available to plants and has a half life of 20-50 yr. Crops may continue to respond to the residual fertilizer $\mathrm{N}$ for several years. Non-tracer work with forages seems to indicate that this may occur (Power et al. 1973; Read 1974; Leyshon and Kilcher 1976). Under irrigation the increased plant growth improves the chances of recovering most of the fertilizer $\mathrm{N}$ from the profile.

At rates of fertilizer $\mathrm{N}$ equal to or less than $82 \mathrm{~kg} / \mathrm{ha}, 73 \%$ or more of the residual $\mathrm{N}$ was located in the top $30 \mathrm{~cm}$ of the soil profile under dryland conditions (Table 4).
At higher rates of N, $50 \%$ of the residual $\mathrm{N}$ was leached into the $30-$ to $60-\mathrm{cm}$ segment by heavy rains which occurred between anthesis and maturity. Since the plants had made more thorough use of the fertilizer $\mathrm{N}$ under irrigation, very little residual $\mathrm{N}$ was left for leaching when the rains came; consequently, only at $164 \mathrm{~kg} \mathrm{~N} / \mathrm{ha}$ was there appreciable movement of residual fertilizer $\mathrm{N}$ into the $30-$ to $60-\mathrm{cm}$ segment (Table 4). There was an average of $4 \%$ of the residual fertilizer $\mathrm{N}$ located in the 60 - to $90-\mathrm{cm}$ segment and none below this depth. Thus there was no leaching loss.

\section{Nitrogen Balance}

The fertilizer $\mathrm{N}$ recovery data were averaged over the levels of applied $\mathrm{N}$ to provide a mean balance sheet (Fig. 2). The original replicate data for the various treatments were used to calculate the confidence limits $\left( \pm t_{.01} \times S_{\overline{\mathrm{x}}}\right)$ at the $1 \%$ level of probability for the average total $\mathrm{N}$ recovery; this was found to be $\pm 6 \%$. There was considerably more of the fertilizer $\mathrm{N}$ left in the dryland soil $(34.6 \%)$ than in the irrigated soil (15.4\%); and there was much less fertilizer $\mathrm{N}$ recovered in the grain of dryland wheat $(37.3 \%)$ than in the grain of irrigated wheat $(58.3 \%)$. Both of these responses were directly related to dry matter production (Campbell et al. 1977b). Moisture had a minimal effect on the average fertilizer $\mathrm{N}$ recovery in straw and roots. The average proportion of the fertilizer $\mathrm{N}$ that was not accounted for in the plant plus the soil (to $105 \mathrm{~cm}$ ) was $7 \%$ for dryland and $4 \%$ under

Table 4. Location of residual fertilizer $\mathrm{N}$ in soil profile

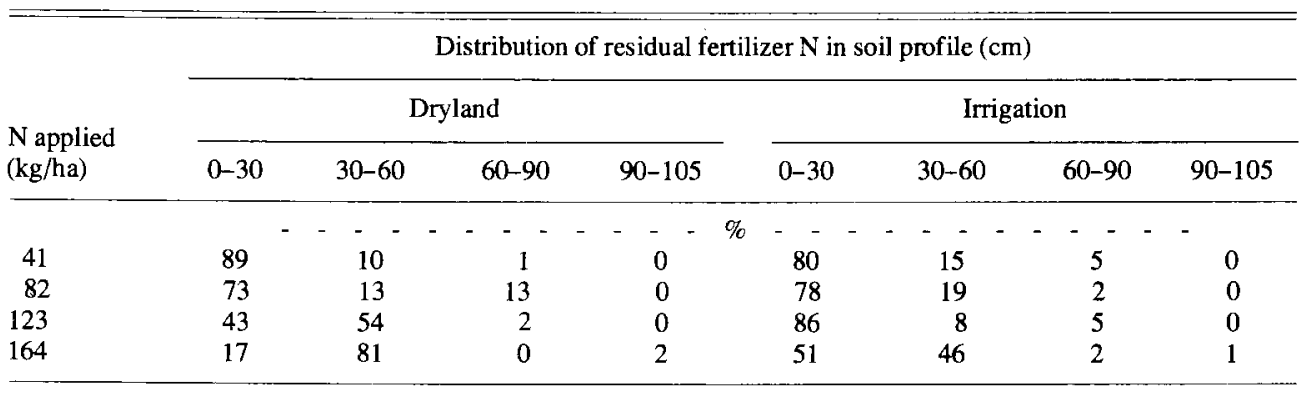



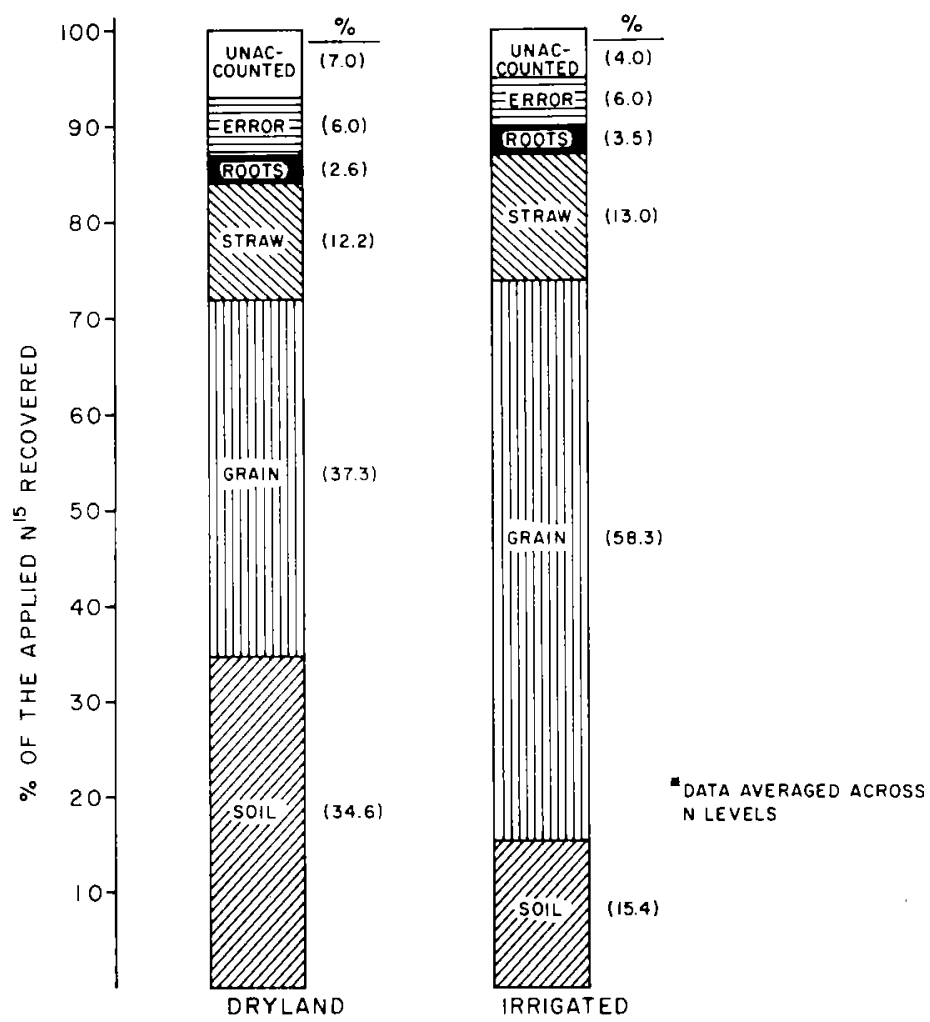

Fig. 2. Average balance sheet of ${ }^{15} \mathrm{~N}$ (error refers to confidence limits at $P<0.01$ ).

irrigation. These amounts, unaccounted for, were assumed to have been denitrified, although there is the possibility that some of the loss could be due to the shedding of pollen (Rumberg and Sneva 1970). We can also assume that there was no effect of irrigation on denitrification in this experiment. Water was applied with this objective in mind.

Kundler (1970) has reported that 1st yr recoveries under a variety of experimental conditions indicate $\mathrm{N}$ recovery in the plant to range between 30 and $70 \%$ (we recovered $53-75 \%$ ), with $10-40 \%$ left in the soil (we found $15-35 \%), 5-10 \%$ lost by leaching (we had none) and 10-30\% unaccounted for (we found about 4-7\% unaccounted for). The low losses via denitrification are in contrast to the findings of numerous workers who report extensive losses by this means (Broadbent and Clark 1965), but agree with those of Craswell and Martin (1974) who reported very little denitrification in a well-structured clay soil at moisture content up to $90 \%$ (by weight).

Under dryland farming conditions usually only the $\mathrm{N}$ in grain and that lost by denitrification are removed from the system; thus, of the $\mathrm{N}$ applied, an average of $56 \%$ (dry) and $38 \%$ (wet) would be left to replenish the soil organic matter. The roots and straw contained about $16 \%$ of the fertilizer $\mathrm{N}$ and they would go directly into the active organic matter pool of $\mathrm{N}$.

\section{CONCLUSIONS}

In contrast to reports in the literature, we found that uptake of soil $\mathrm{N}$ and A-values generally decreased with increasing fertilizer $\mathrm{N}$, while increased availability of 
native soil $\mathrm{N}$ only occurred at the highest rates of fertilizing, particularly under dryland conditions. We also found a plateau for fertilizer $\mathrm{N}$ uptake. In our opinion, one of the main contributors to this difference in results was that most results in the literature accrue from pot-culture studies and these often do not provide a realistic simulation of response under field conditions. For example, it distorts root distribution, results in a much lower soil $\mathrm{N} /$ fertilizer $\mathrm{N}$ ratio than exists in the field, and it usually permits much greater dry matter production, which in turn provides a much greater sink for $\mathrm{N}$ assimilation.

A considerable proportion of the fertilizer remained in the soil under dryland conditions $(28-57 \%)$. The nature of this $\mathrm{N}$ was not determined but it seems reasonable to assume that this residual $\mathrm{N}$ would represent a greater pollution potential if the field was summer-fallowed rather than cropped the following year. The very low residual $\mathrm{N}$ and denitrification and leaching losses experienced under the irrigated system indicate that it is fallacious to assume that irrigation will necessarily result in greater pollution. The rate and timeliness of irrigation, the rate and type of fertilizer applied, the amount and rate of crop growth, and the soil type will interact to determine the amount and distribution of the fertilizer $\mathrm{N}$ that appears in the soil, plant, air or groundwater.

Ideally, minimum pollution will occur if soil moisture is good in the spring so as to promote rapid growth and uptake of $\mathrm{N}$; plants take up most of their $\mathrm{N}$ at an early growth stage (Viets 1965; Campbell et al. 1977b). This should be followed by good rainfall when the plant is making its maximum growth to allow continued plant development and $\mathrm{N}$ uptake and reduce leaching and denitrification losses. If too much rainfall occurred, or too much irrigation was administered at too early a stage, $\mathrm{NO}_{3}-\mathrm{N}$ could be leached out of the root zone before it could be assimilated. On the other hand, if the soil became very dry, and especially if this occurred at an early growth stage, dry matter production will be reduced (small $\mathrm{N}$ sink) and this may even result in the exudation of plant $\mathrm{N}$ into the soil (Allison 1973; Campbell et al. 1977a).

ALEKSIC, Z., BROESHART, $H$, and MIDDLEBOW, $V$. 1968. The effect of nitrogen fertilization on the release of soil nitrogen. Plant Soil 29: 474-478.

ALLISON, F. E. 1966. The fate of nitrogen applied to soils. Adv. Agron. 18: 219-258.

ALLISON, F. E. 1973. Soil organic matter and its role in crop production. In Developments in soil science 3. Elsevier, Amsterdam. 637 pp.

BREMNER, J. M. 1965. Total nitrogen. Pages 1149-1178. in C. A. Black et al., eds. Method of soil analysis. Part 2. Chemical and microbiological properties. Amer. Soc. Agron. Inc., Madison, Wis.

BROADBENT, F. E. 1970. Variables affecting A-values as a measure of soil nitrogen availability. Soil Sci. 110: 19-23.

BROADBENT, F. E. and CLARK, F. E. 1965. Denitrification. Pages 344-359 in W. V. Barthelomew and F. E. Clark, eds. Soil nitrogen. Agronomy 10. Amer. Soc. Agron. Inc. Madison, Wis.

BROADBENT, F. E. and NAKASHIMA, T. 1967. Reversion of fertilizer nitrogen in soil. Soil Sci. Soc. Amer. Proc. 31: 648-652.

BROADBENT, F. E. and NAKASHIMA, T. 1971. Effect of added salts on nitrogen mineralization in three California soils. Soil Sci. Amer. Proc. 35: 457-460.

CAMPBELL, C. A., CAMERON, D. R., NICHOLAICHUK, W. and DAVIDSON, H. R. 1977a. Effect of fertilizer $\mathrm{N}$ and soil moisture on growth, $\mathrm{N}$ content and moisture use by spring wheat. Can. J. Soil Sci. 57: 289-310.

CAMPBELL, C. A., DAVIDSON, H. R. and WARDER, F. G. 1977b. Effect of fertilizer N and soil moisture on yield, yield components, protein content and $\mathrm{N}$ accumulation in the aboveground parts of spring wheat. Can. J. Soil Sci. 57: 311-327.

CARTER, J. N., BENNETT, O. L. and PEARSON, R. W. 1967. Recovery of fertilizer nitrogen under field conditions using nitrogen15. Soil Sci. Soc. Amer. Proc. 31: 50-56.

CRASWELL, E. T. and MARTIN, A. E. 1974. Effect of moisture content on denitrification in a clay soil. Soil Biol. Biochem. 6: 127-129. 
DYCK, F. B., CAMPBELL, C. A. and McLAUGHLIN, N. B. 1977. Equipment and methods for isolating soil cores. Can. J. Plant Sci. 57: 537-541.

FORD, G. W., JESSOP, R. S. and MARTIN, J. J. 1974. Factors influencing nitrogen availability in Wimera wheat soils. Proc. 10th Int. Congr. Soil Sci. 9: 39-48.

GREENWOOD, D. J., WOOD, J. T. and CLEAVER, T. J. 1974. A dynamic model for the effects of soil and weather conditions on nitrogen response. J. Agric. Sci. 82: 455-467.

HAUCK, R. D. 1973. Nitrogen tracers in nitrogen cycle studies - past use and future needs. J. Environ. Qual. 2: 317-327.

JANSSON, S. L. 1963. Balance sheet and residual effects of fertilizer nitrogen in a six-year study with ${ }^{15} \mathrm{~N}$. Soil Sci. 95: 31-37.

KUNDLER, P. 1970. Utilization, fixation and loss of fertilizer nitrogen (review of international results of the last 10 years research). Albrecht Thaer Arch. 14: 191-210.

LAURA, R. C. 1976. Effects of alkali salts on carbon and nitrogen mineralization of organic matter in the soil. Plant Soil 44: 587-596.

LEGG, J. O. and STANFORD, G. 1967. Utilization of soil and fertilizer $N$ by oats in relation to the available $\mathrm{N}$ status of soils. Soil Sci. Soc. Amer. Proc. 31: 215-219.

LEGG, J. O., CHICHESTER, F. W., STAN FORD, G. and DEMAR, W. H. 1971. Incorporation of ${ }^{15} \mathrm{~N}$ tagged mineral nitrogen into stable forms of soil organic nitrogen. Soil Sci. Soc. Amer. Proc. 35: 273-276.

LEYSHON, A. J. and KILCHER, M. R. 1976. High nitrogen fertilizer applications on grasses and the long term residual effects. Pages 114-120 in Proc. Soil. Fertil. Workshop, University of Saskatchewan, Saskatoon, Sask.

MITCHELL, J., MOSS, H. C., CLAYTON, J. S. and EDMUNDS, F. H. 1944. Soil survey report no. 12, University of Saskatchewan, Saskatoon, Sask.

MYERS, R. J. K. and PAUL, E. A. 1971. Plani uptake and immobilization of ${ }^{15} \mathrm{~N}$ labelled ammonium nitrate in a field experiment with wheat. Pages 55-64 in Proc. FAO/IAEA meeting on recent developments in the use of ${ }^{15} \mathrm{~N}$ in soil-plant studies.

OVERREIN, L. N. 1972. Tracer studies on the internal nitrogen cycle in forest soil. Medd. Nor. Skogforsoksves. 116: 445-466.

PAUL, E. A., RENNIE, D. A., SCHAPPERT,
H. J. V. and McGILL, K. S. 1972. Crop Utilization and fate of fertilizer nitrogen in soil. Pages 79-132 in Soil-plant nutrient research report. Sask. Inst. Pedol. Rep. No. M23.

POWER, J. F., ALESSI, G. A., REICHMAN, G. A. and GRUNES, D. I. 1973. Recovery, residual effects and fate of nitrogen fertilizer sources in a semiarid region. Agron. J. 65: 765-768.

READ, D. W. L. 1974. Residual $N$ for dryland forage crops. Pages 132-134 in Proc. Soil Fertil. Workshop, Univ. of Saskatchewan, Saskatoon, Sask.

RENNIE, D. A. and FRIED, M. 1971. An interpretive analysis of the significance in soil fertility and fertilizer evaluation of ${ }^{15} \mathrm{~N}$ labelled fertilizer experiments conducted under field conditions. Proc. Int. Symp. Soil Fertil. Evaluation, New Delhi 1: 639-656.

RENNIE, D. A and PAUL, E. A. 1971. Isotope methodology and techniques in soil-plant nutrition and plant physiology. University of Saskatchewan Press. 142 pp.

ROVIRA, A. D. and McDOUGALL, B. $\mathbf{M}$. 1967. Microbiological and biochemical aspects of the rhizosphere. Pages 418-463. in A. D. McLaren and G. H. Petersen, eds. Soil biochemistry. Vol. 1. Marcel Dekker Inc., New York, N.Y.

RUMBERG, C. B. And SNEVA, A. 1970. Accumulation and loss of nitrogen during growth and maturation of cereal rye (Secale cereale). Agron. J. 62: 311-313.

SHIELDS, J. A., PAUL, E. A. , LOWE, W. E. and PARKINSON, D. 1973. Turnover of microbial tissue in soil under field conditions. Soil Biol. Biochem. 5: 753-764.

SMITH, S. J. and LEGG, J. O. 1971. Reflections on the A value concept of soil nutrient availability. Soil Sci. 112: 373-375.

SOPER, R. J., RACZ, G. T. and FEHR, P. I. 1971. Nitrate nitrogen in the soil as a means of predicting the fertilizer nitrogen requirements of barley. Can. J. Soil Sci. 51: 45-49.

STEEL, R. G. D. and TORRIE, J. H. 1960. Principles and procedures of statistics. McGraw-Hill Book Co., Inc., New York, N.Y. 481 pp.

TERMAN, G. L. and BROWN, M. A. 1968. Crop recovery of applied fertilizer nitrogen. Plant Soil. 29: 48-65.

VIETS, F. G., Jr. 1965. The plant's need for and use of nitrogen. Pages 503-549 in W. V. 
Bartholomew and F. E. Clark, eds. Soil experiments. Soil Sci. Soc. Amer. Proc. 38: nitrogen. Agronomy 10. Amer. Soc. Agron., 107-109.

Madison, Wis.

WESTERMAN, R. L. KURTZ, L. T. and

WESTERMAN, R. L. and KURTZ, L. T. 1974. HAUCK, R. C. 1972. Recovery of ${ }^{15}$ N labelled Isotopic and non-isotopic estimations of fer- fertilizers in field experiments. Soil Sci. Soc. tilizer nitrogen uptake by Sudangrass in field Amer. Proc. 36: 82-86. 